\title{
МІСЦЕ І РОЛЬ ДЕРЖАВНОЇ МИТНОЇ СЛУЖБИ У СИСТЕМІ ЗАБЕЗПЕЧЕННЯ МИТНОӤ ПОЛІТИКИ УКРАЇНИ ТА РЕФОРМУВАННЯ МИТНИХ ОРГАНІВ УЦІЛОМУ
}

\author{
БАСС Вікторія Олександрівна - кандидат юридичних наук, доцент кафедри \\ поліцейського права Національної академії внутрішніх справ \\ DOI:10.32782/EP.2020.1.2 \\ УДК 342.951:351.713
}

На основе детального анализа развития таможенного дела через призму европейского контента от зарождения прообразов таможенных органов до бормирования Европейского Союза как современного национального образования, прослеженъ чертъл, общей закономерности и тендениии развития. На разнъх этапах формирования системъ таможенных органов они были основнылм фактором развития государства Украина, менялись вместе с изменением типов и форм государственности, что отражалось на статусе и роли, месте таможенных органов и Государственной таможенной службъ, в частности, в системе государственнъхх инcтитутов.

Ключевъе слова: Таможеннъе органъ, государственная политика, Государственная Таможенная служба Украинъ, ребормирование таможенных органов .

Актуальність теми

Сьогодні, основними напрямами митної справи є захист інтересів держави, а також контроль за додержанням прав, боротьба 3 контрабандою, модернізація митних органів та створення сприятливих умов для виходження України на міжнародний рівень шляхом участі у міжнародних організаціях, поглибленням міжнародного співробітництва та адаптації українського законодавства до європейських стандартів.

Законодавство України з питань митної справи складається з Конституції України,
Митного Кодексу, інших законів України, що регулюють питання, зазначені у статті 7 Митного Кодексу України, з міжнародних договорів України, згода на обов'язковість яких надана Верховною Радою України, а також з нормативно-правових актів, виданих на основі та на виконання цього Кодексу та інших законодавчих актів.

Відносини, пов'язані із справлянням митних платежів, регулюються Кодексом, Податковим кодексом України та іншими законами України з питань оподаткування.

Aле якщо міжнародним договором України, згода на обов'язковість якого надана Верховною Радою України, встановлено інші правила, ніж ті, що передбачені цим Кодексом та іншими законами України, застосовуються правила міжнародного договору України [1].

\section{Стан дослідження даної теми}

Вчені, які досліджували дану проблематику О.М. Бандурка, В.М. Бойко, Б.М. Габрічідзе, В.Г. Драганов, Ю.М. Дьомін, А.М. Дорофєєва, О.Б. Егоров, Ф.А. Жорін, В.О. Заросило, А.Б. Калюта, О.В. Кіян, В.К. Колпаков, Т.В. Корнєва, Т.В. Курило, В.І. Аитвиненко, М.В. Аошицький, В.П., К.В. Муравйов, Науменко, О.П. Ноздрачов, Ю.В. Оніщик, А.В. Павлов, П.В. Пашко, В.В. Прокопенко, Н.В. Прусакова, В.В. Романенко, С.С. Терещенко, Т.М. Трошкіна, С.А. Чернявський, Р.Б. Шишка, М.Г. Шульга та інші, 
мали різні погляди та квінтесенції із вирішення правових питань забезпечення та реалізації митної політики України.

Об’єктом дослідження виступають суспільні відносини у сфері забезпечення митної політики України та реформування митних органів.

На основі аналізу історичного розвитку митної справи через призму європейського контенту від зародження праобразів митних органів до формування Европейського Союзу як сучасного національного утворення, прослідковано риси, загальної закономірності та тенденції розвитку. На різних етапах формування системи митних органів вони були основним чинником розвитку держави Україна, змінювались разом із зміною типів і форм державності, що відображалося на статусі та ролі, місці митних органів у системі державних інститутів. У своїй статті ми акцентуємо увагу на формуванні функціональної діяльності митних органів в той час як до первинної фіскальної місії митників додано захисну, наглядову (контрольну), регуляторну, статистичну, а також звернуто увагу на внутрішній організації митної служби і особливих вимогах, що в усі часи висувались до уповноважених осіб, у частину професійних обов'язків яких входили такі обов'язки.

\section{Виклад основного матеріалу}

Державна митна служба України (Держмитслужба) є центральним органом виконавчої влади, діяльність якого спрямовується та координується Кабінетом Міністрів України через Міністра фінансів.

Держмитслужба реалізує державну митну політику, державну політику у сфері боротьби з правопорушеннями під час застосування законодавства 3 питань державної митної справи.

Держмитслужба у своїй діяльності керується Конституцією та законами України, актами Президента України та постановами Верховної Ради України, прийнятими відповідно до Конституції та законів України, актами Кабінету Міністрів України, іншими актами законодавства.
Основними завданнями Держмитслужби 6 :

1) забезпечення реалізації державної митної політики, зокрема забезпечення митної безпеки та захисту митних інтересів України і створення сприятливих умов для розвитку зовнішньоекономічної діяльності, збереження належного балансу між митним контролем і спрощенням законної торгівлі;

2) забезпечення реалізації державної політики у сфері боротьби з правопорушеннями під час застосування законодавства 3 питань державної митної справи, запобігання та протидії контрабанді, боротьби з порушеннями митних правил;

3) внесення пропозицій щодо забезпечення формування державної митної політики на розгляд Міністра фінансів [2].

Стаття 3 Закону України «Про стимулювання розвитку вітчизняного машинобудування для агропромислового комплексу» визначає основні завдання вітчизняного машинобудування для агропромислового комплексу.

До них належать:

1) забезпечення потреб агропромислового комплексу вітчизняною технікою і обладнанням для впровадження сучасних технологій у виробництво, зберігання та переробку сільськогосподарської продукції;

2) проведення науково-технічної політики розвитку машинобудування для агропромислового комплексу, сприяння підвищенню рівня технологічних процесів та екологічної безпеки;

3) участь у розробленні стандартів відповідно до закону;

4) впровадження наукових досліджень, дослідно-конструкторських, технологічних та проектних розробок комплексного характеру, пов'язаних 3 розвитком виробництва техніки і обладнання для агропромислового комплексу;

5) визначення обсягів виготовлення і координація виробництва у номенклатурі техніки і обладнання для агропромислового комплексу, впровадження технічного обслуговування та освоєння прогресивних технологій ремонту техніки; 


\section{Адміністративне право}

6) сприяння скороченню витрат енергетичних і матеріальних ресурсів при виготовленні, технічному обслуговуванні та ремонті техніки і обладнання для агропромислового комплексу, підвищенню надійності та збільшенню термінів їх експлуатації;

7) участь у розробці програм соціального та економічного розвитку села, сприяння комплексній поставці техніки і обладнання для агропромислового комплексу сільськогосподарським товаровиробникам і підприємствам харчової та переробної промисловості;

8) розробка проектів програм розвитку вітчизняного машинобудування для агропромислового комплексу у порядку, визначеному законодавством;

9) виконання програм виробництва технологічних комплексів машин і обладнання для агропромислового комплексу, стимулювання освоєння виробництва нової техніки і обладнання для агропромислового комплексу, підвищення відповідальності промислових підприємств за якість виготовлюваної техніки, створення системи їі технічного обслуговування та ремонту;

10) розширення мережі підприємств 3 реалізації, технічного обслуговування, ремонту, надання у користування (зокрема за договорами фінансового лізингу) техніки і обладнання для агропромислового комплексу;

11) формування та розвиток ринку техніки і обладнання для агропромислового комплексу;

12) розробка пропозицій щодо удосконалення умов фінансування, оподаткування, кредитування, особливостей приватизації підприємств вітчизняного машинобудування для агропромислового комплексу;

13) здійснення економічних та організаційних заходів, спрямованих на зростання експортного потенціалу, збільшення обсягів реалізації техніки і обладнання для агропромислового комплексу в Україні та за їі межами;

14) залучення вітчизняних та іноземних інвестицій для освоєння виробництва нової техніки і обладнання для агропро- мислового комплексу, оновлення основних фондів, технічного переозброєння i реконструкції підприємств вітчизняного машинобудування для агропромислового комплексу;

15) реалізація державної політики зайнятості, забезпечення висококваліфікованими кадрами підприємств вітчизняного машинобудування для агропромислового комплексу;

16) розвиток міжнародного співробітництва підприємств вітчизняного машинобудування для агропромислового комплексу [3].

Так, тимчасово, на період реалізації контракту, укладеного для реалізації національного проекту «Повітряний експрес», затвердженого Кабінетом Міністрів України, яким передбачено спорудження залізничного пасажирського сполучення м. Київ - міжнародний аеропорт «Бориспіль», будівництво міської кільцевої автомобільної дороги навколо м. Києва на ділянці Київ - Бориспіль, будівництво дороги від Подільського мостового переходу до проспекту Ватутіна у м. Києві, товари (крім підакцизних), що не виробляються в Україні або не відповідають вимогам проекту, що ввозяться на митну територію України у митному режимі імпорту з метою їх використання для реалізації національного проекту «Повітряний експрес» за такими кодами товарів згідно з УКТ ЗЕд: $6801000000,6809110000,6901000000$, $7005108000,7216401000,7216409000$, $7216911000,7408110000,7412200000$, $8405100000,8414409000,8428102000$, $8428400000,8428909500,8429110000$, $8429190000,8429200000,8429300000$, $8429409000,8430100000,8504409000$, $8530800000,8601100000,8602900000$, $8608001000,8608003000,8704229100$, $8704239100,8705300090,8705909090$, $8716800000,9015401000,9405990090$, 8504108010 .

Порядок та обсяги ввезення таких товарів визначаються Кабінетом Міністрів України.

до 1 січня 2018 року - устаткування (обладнання) та комплектуючі вироби до нього, що ввозяться суб'єктами господарюван- 
ня виключно для реалізації інвестиційних проектів, схвалених відповідно до Закону України «Про стимулювання інвестиційної діяльності у пріоритетних галузях економіки з метою створення нових робочих місць», за умови, що зазначені товари:

а) не $є$ підакцизними;

б) виготовлені не більше трьох років до моменту державної реєстрації інвестиційного проекту та не були у використанні;

в) не виробляються в Україні та не мають аналогів в Україні.

Порядок ввезення, перелік та обсяги зазначених товарів 3 визначенням їх кодів згідно з УКТ ЗЕД затверджуються Кабінетом Міністрів України разом із схваленням кожного окремого інвестиційного проекту.

У даному контексті терміни вживаються в такому значенні:

устаткування (обладнання) - машини (крім транспортних засобів), механізми, прилади, пристрої, призначені для використання у технологічному процесі, що здійснюється під час реалізації інвестиційного проекту;

комплектуючі вироби до устаткування (обладнання) - частини, виготовлені згідно із самостійним комплектом документів і призначені для застосування у складі такого устаткування (обладнання) [1].

На даний час надзвичайно зросла роль держави у регулюванні зазначених процесів у сфері зовнішньоекономічної діяльності. Загострюється потреба підвищення ефективності національної митної політики в сфері реагування на зовнішні загрози та швидкої протидії можливим негативним наслідкам таких загроз у напрямку посилення забезпечення економічних інтересів держави й максимального врахування в національній митній системі міжнародних правил та вимог. Держава в особі уповноважених органів повинна здійснювати це регулювання, ураховуючи питання, пов'язані зі стимулюванням розвитку і структурної перебудови національної економіки та її захистом. Одним 3 основних важелів, який використовується для регулювання зовнішньої торгівлі та захисту національних інтересів у цій сфері, є митна політика держави

Відповідно до ст. 3 Митного Кодексу України Державна митна політика - це система принципів та напрямів діяльності держави у сфері захисту митних інтересів та забезпечення митної безпеки України, регулювання зовнішньої торгівлі, захисту внутрішнього ринку, розвитку економіки України та їі інтеграції до світової економіки. Державна митна політика є складовою частиною державної економічної політики [1].

Проблеми сучасної митної політики визначають стратегію розвитку митної діяльності як сьогодення, так і майбутнього. Це пов'язано 3 цілим комплексом факторів об'єктивного та суб'єктивного характеру. Так, формування й реалізація митної політики держави об'єктивно спричинені закономірностями і тенденціями розвитку міжнародних зв'язків та відносин, 3 одного боку, умовами, закономірностями і тенденціями соціально-економічного розвитку світової спільноти, з другого. Разом 3 тим, існування суб'єктивних факторів може суттєво вплинути на хід та результат цього процесу. До таких суб'єктивних факторів, перш за все, можемо зараховувати політику конкретної держави в конкретний історичний період іiі існування та фактори, пов'язані з діяльністю національних митних органів [4].

Для України такі фактори, на думку науковців, спричиняються умовами переходу держави до ринкових відносин. Однією 3 найголовніших проблем митної політики України є відставання митного контролю від сучасних потреб пропускної здатності та світових стандартів контролю товарів. Суттєве зростання обсягів зовнішньоторговельного обороту та зміцнення цих тенденцій вимагає якісно нового підходу до здійснення контролю міжнародних вантажних потоків. Зростання товаропотоків висвітлило такі проблеми митного контролю як суттєві часові витрати на проведення митних процедур та застарілі механізми. Про значну недосконалість митної політики України свідчать також: значний вміст товарів, що переміщуються контр- 


\section{Адміністративне право}

абандним шляхом; збереження загрозливої ситуації з контрабандою наркотичних засобів та зброї; учинення правопорушень у сфері інтелектуальної власності та інші. Також однією із важливих проблем митної політики України $є$ експортно-імпортні операції через офшорні зони. Негативним чинником є також збереження тенденцій щодо кількісно зареєстрованих в Україні учасників зовнішньоекономічної діяльності (ЗЕД) та їх фактичною активністю в сфері зовнішньої торгівлі. Враховуючи розглянуті тенденції та умови функціонування митної політики в Україні, науковцями визначені пріоритети у цій сфері. Ними мають стати: підвищення рівня захисту національних інтересів держави 3 одночасним упровадженням міжнародних вимог та стандартів; спрощення митних процедур; створення максимально сприятливого середовища для учасників ЗЕД; підвищення ефективності виявлення та протидії негативним явищам у середовищі зовнішньої торгівлі [5].

Отже, необхідно здійснити ряд заходів, які посилять рівень захисту національних інтересів держави, створять сприятливі умови для збільшення обсягів зовнішньої торгівлі та позитивно вплинуть на соціальний та економічний розвиток України. Зокрема,одним із важливих кроків до побудови ефективної митної політики нашої держави є здобуття нею авторитету цінного і надійного партнера в системі світового співробітництва. Світове співробітництво вимагає ефективної логістики, чітких та зрозумілих правил торгівлі, вмілого менеджменту митної політики, використання сучасних інформаційних і комунікаційних технологій. Але, налагоджуючи відносини на міжнародному рівні, необхідно пам'ятати, що однією з основних функцій митної політики $є$ захист національних інтересів, і будь-які дії митної політики повинні здійснюватись 3 акцентуванням уваги на цей чинник. У цьому напрямку доцільно використовувати протекціоністські заходи на основі гнучких і новітніх методів, які 6 не зашкодили розвитку міжнародних відносин України.

= Свропейські перспективи № 1, $2020=$

\section{Висновки}

Виходячи 3 фактичного рівня організаційного забезпечення функціонування митних органів України, і Державної митної служби, зокрема необхідно комплексно та ефективно адаптувати їх діяльність до визнаних у міжнародному співтоваристві норм і стандартів. У рамках Концепції реформування митної служби України на 2019 - 2029 роки ми спробували деталізувати найбільш важливі складові змін у діяльності Національних митних органів, а також запропоновано оптимальну структурно-організаційну систему. Необхідно на законодавчому рівні виокремити елементи Концепції, розробленої 3 урахуванням узятих на себе міжнародних зобов'язань держави Україна (Угода про асоціацію України та $\mathrm{EC}$, участь в міжнародних організаціях і приєднання до міжнародних угод універсального характеру 3 митних питань) та необхідності формування ефективної моделі управління системою митних органів. Стратегічним напрямком реформування митних органів України назване максимальне наближення організації їх діяльності до визнаних у світі стандартів, а пріоритетом - концептуально новий порядок взаємодії митниць з суб'єктами зовнішньоекономічної діяльності та громадянами, який вимагає

Утворення відносно нової для українського суспільства платформи соціального партнерства.

\section{Мітература}

1. Митний кодекс України: Кодекс від 13 березня 2012 року № 4495-VI // [Електронний ресурс] - Режим доступу: https:// zakon.rada.gov.ua/laws/show/4495-17.

2. Про затвердження положень про Державну податкову службу України та Державну митну службу України: Постанова Кабінету Міністрів України від 6 березня 2019 р. № 227 // [Електронний ресурс] - Режим доступу: https://zakon.rada. gov.ua/laws/show/227-2019-\%D0\%BF\#n209.

3. Про стимулювання розвитку вітчизняного машинобудування для агропромислового комплексу: Закон України від 7 лютого 2002 року № 3023-III// [Елек- 
Басс В.О. - Місце і роль державної митної служби у системі забезпечення...

\section{АНОТАЦІЯ}

На основі детального аналізу розвитку митної справи через призму європейсъкого контенту від зародження праобразів митних органів до бормування Европейсъкого Союзу як сучасного національного утворення, прослідковано риси, загальної закономірності та тендениї розвитку. На різних етапах формування системи митних органів вони були основним чинником розвитку держави Україна, змінювались разом із зміною типів $і$ борм державності, що відображалося на статусі та ролі, місиі митних органів $і$ Державної Митної служби, зокрема, у системі державних інcтитутів.

Ключові слова: Митні органи, державна політика, Державна Митна служба України, ребормування митних органів.

тронний ресурс] - Режим доступу: https:// zakon.rada.gov.ua/laws/show/3023-14.

4. Пашко П.В., Пісной П.Я. Митна політика та митна безпека України// Фінанси України - 2007. -No1. - C.74-79.

5. Артеменко Д.В., Бабенко А.Г., Гавриленко Б.В. і ін. Торгівля через оф-

\section{SUMMARY}

On the basis of a detailed analysis of the development of customs through the prism of European content from the emergence of prototypes of customs authorities to the formation of the European Union as a modern national formation, traits, general patterns and trends of development are traced. At different stages of the formation of the system of customs authorities, they were a major factor in the development of the state of Ukraine, changing with the change of types and forms of statehood, which reflected on the status and role, place of customs authorities and the State Customs Service, in particular, in the system of state institutions.

Keywords: Customs Authorities, State Policy, State Customs Service of Ukraine, Reform of Customs Authorities.

шорні зони: раціональна необхідність чи перепона для розвитку України// Журнал «Спільне» - 2016, [Електронний ресурс]. Режим доступу: http://commons.com.ua/uk/ torgivlya-cherez-ofshornizoni-ratsionalnaneobhidnist-chi-perepona-dlya-rozvitkuukrayini. 